\title{
JAN PAWEL II A 1600. ROCZNICA ŚMIERCI ŚW. AMBROŻEGO (List apostolski ,Operosam diem”)
}

List Apostolski Operosam diem został wydany przez papieża Jana Pawła II dnia 1 grudnia 1996 roku$^{1}$. Miał on zapoczątkować rok św. Ambrożego obchodzony z okazji 1600-lecia jego śmierci (397) i być nawiązaniem do „tertio millennio christianitatis adveniente". Ta druga okazja wpłynęła też w znacznym stopniu na ukierunkowanie jego treści wydobywanych z nauczania Biskupa, dotyczących zwłaszcza doktryny chrystologicznej. List rozpoczyna się od przypomnienia sceny śmierci św. Ambrożego, jaką opisał jego biograf Paulin, a mianowicie, że umierał z rozłożonymi niby na krzyżu rękoma ${ }^{2}$ (w kompozycji Listu zapowiedź akcentu chrystologicznego). Św. Ambroży jawi się tu zaraz jako Boży mąż, który w pełnieniu biskupiej posługi zrealizował swoje życie w ,harmonii i spójności”:
„Dzielny i łagodny pasterz, człowiek zdolny zarówno do napominania, jak i do wybaczania, nieubłagany wobec błędów, cierpliwy jednak w odniesieniu do błą- dzących, surowy wobec panujących, a jednocześnie szanujący państwo, pozostają- cy w przyjaznych stosunkach z cesarzami, a jednak bliski swojemu ludowi, docie- kliwy uczony i niezmordowany człowiek czynu"”.

Tak sformułowana synteza ukazuje nie tylko osobę i postawę wielkiego Biskupa, ale i jego działalność w trudnych czasach przemieniającego się chrześcijaństwa i życia Kościoła w okresie ścierania się poglądów ortodoksyjnych z naukami heretyckimi i to nie tylko w sferze doktryny, ale także całym zakresie życia i działania.

Wsłuchiwanie się w nauczanie i wpatrywanie się w działalność św. Ambrożego sprawia, że te dwie epoki, miniona i obecna, przez wiarę spotykają się w każdej wspólnocie kościelnej. List sugeruje ciekawą doktrynę, a mianowicie:

${ }^{1}$ Tekst Listu Operosam diem zob. AAS 89 (1997) 217-239, polski przekład VoxP 16 (1996) t. $30-31,7-32$.

${ }^{2}$ Por. Paulinus, Vita Ambrosii 47, 1-2; Operosam diem 1.

3 Operosam diem 2, VoxP t. 30-31, s. 2. 
„Właściwością świętych jest faktyczne trwanie w tajemniczy sposób jako wspótcześni wszystkim wiekom: wypływa stąd wniosek, że są oni zakorzenieni w wiecznej teraźniejszości Boga" ${ }^{4}$.

Tak określone jest to, co stanowi jakby podstawę ciągle trwającej aktualności nauczania Ojców. U św. Ambrożego - jak ukazuje List - przygotowanie do przepowiadania miało szczególny charakter i wynikało z osobistej i bardzo świadomej gorliwości celowo nastawionej na działanie pasterskie. W swoim nauczaniu, jak wiadomo, powtarzał wiedzę, jaką sobie przyswoił, ale uzupełniał ją własnymi poglądami, tworząc zwięzłe, mimo retorycznego rozmachu, i skuteczne sformułowania dostosowane do sytuacji ludzi odbierających jego teksty mówione lub pisane.

Św. Ambroży objął stolicę mediolańską po blisko dwudziestoletnich rządach ariańskiego biskupa Auksencjusza. Wszedł więc w środowisko przesiąknięte duchem arianizmu, któremu on jako biskup musiał się koniecznie przeciwstawić. Czynił to zaś na dwóch płaszczyznach - nauczania i działania; nauczał i pisał traktaty skierowane przeciw arianom i bronił Kościoła w Mediolanie ${ }^{5}$.

Z walką o prawowierność chrześcijańską wiązała się konieczność tworzenia i pogłębiania nowych podstaw moralnych i społecznych, aby kierować powszechnym odradzaniem się społeczeństwa tego czasu przez wprowadzanie zasad ewangelicznych. Prowadziło to także do konieczności przeciwstawiania się wpływom zamierającego z godnością pogaństwa, jak na to wskazuje patetyczny spór z Symmachem, oraz wprowadzanie nowych zasad broniących sprawiedliwości w rozwijającej się żywotnie społeczności; poświęcił temu szereg pism, na które powołuje się dokument papieski.

Św. Ambroży wchodzi jednak w życie społeczności chrześcijańskiej jeszcze głębiej. Tworzy przez swoją działalność swoisty, jak to określa List, ,,przewodnik duchowy", który prowadzi do poznawania Słowa Bożego, do życia sakramentalnego i modlitwy liturgicznej w ramach uporządkowanego przykazaniami Bożymi życia chrześcijan ${ }^{6}$. To sprawiło, że wielki Augustyn uznał go za „ojca swojej wiary"7. W działalności św. Ambrożego ukazują się na różny sposób różne płaszczyzny - troska o duchowieństwo, o konsekrowane dziewice, o kult męczenników, o ryty liturgiczne przez zachowywanie pewnych odrębności i przez ich objaśnianie, szczególnie w związku z inicjacją, i o swoiste uzupełnianie liturgii, zwłaszcza przez wprowadzanie hymnów. W Liście jest też pewna próba ukazania duchowości św. Ambrożego jako człowieka „wewnętrznego skupienia i głębokiej kontemplacji” " . Jego skupienie koncentrowało się przede

\footnotetext{
4 Tamże 3, VoxP t. 30-31, s. 9.

5 Por. tamże 6.

${ }^{6}$ Por. tamże 9, VoxP t. 30-31, s. 13.

7 Por. tamże; Augustinus, Confessiones VIII 2.

${ }^{8}$ Por. Operosam diem 11, VoxP t. 30-31, s. 14.
} 
wszystkim na zgłębianiu i wyjaśnianiu Pisma Świętego. Był człowiekiem umartwienia i modlitwy, a obiektem jego najgłębszego umiłowania był sam Chrystus.

Czysto kościelna działalność Biskupa nie wykluczała jego zaangażowania w sprawy społeczno-polityczne i nie pozwalała zapominać o pielęgnowaniu właściwych relacji z władcami imperium i innymi przedstawicielami władzy państwowej. Do tych faktów też nawiązuje List Operosam diem.

Poza omówieniem działalności zewnętrznej św. Ambrożego List Apostolski podkreśla także jego zainteresowania natury teologicznej. Należy do nich m.in. wspomniane już zamiłowanie do wyjaśniania Pisma Świętego, którego księgi komentował z niesłabnącym zapałem doszukując się w nich potrójnego sensu, a mianowicie dosłownego, moralnego i alegoryczno-mistycznego, aby pełniej odkrywać misterium Chrystusa i Kościoła. W słowach „Pij oba kielichy Starego i Nowego Testamentu" " podkreślał, że poznawanie Pisma Świętego w całości jest trudne i wymaga wielkiego i stałego wysiłku. Podawane w Liście Operosam diem cytaty odwołują się do bardzo obrazowych sformułowań św. Ambrożego o łączności między Starym a Nowym Przymierzem. Dokument stawia przy tym tego właśnie Biskupa jako przykład zachęcający wiernych do umieszczania Biblii w centrum życia chrześcijańskiego.

Ponieważ List poświęcony św. Ambrożemu został wydany w pewnym związku z obchodami rozpoczęcia trzeciego tysiąclecia chrześcijaństwa, które miały mieć charakter wyraźnie chrystologiczny, dlatego ukazano w nim także św. Ambrożego jako ,wybitnego nauczyciela doktryny chrystologicznej i trynitarnej po Soborze Nicejskim (325)" "10. Rozważania św. Ambrożego dotyczące Trójcy Świętej, zawarte w kilku jego pismach, sprawiły, że wpłynął on ogromnie na rozwój teologii trynitarnej na Zachodzie, podkreśla Papiez $\dot{z}^{11}$. Zgłębianie tej tajemnicy wiary św. Ambroży łączył ze świadomością, że jej przeniknięcie przekracza zdolności pojmowania umysłu człowieka:

„Wiemy o różnicy Osób, nie znamy jej niezgłębionych tajników, nie roztrząsamy przyczyn, zachowujemy tajemnicę"12.

Rozważania św. Ambrożego - czytamy - dotyczące Wcielenia i Odkupienia zdradzają jego osobiste zaangażowanie wobec faktu, że przez Wcielenie Chrystus połączył się z ludzkością więzami najgłębszej miłości, która szczególnego blasku i wzniosłości nabrała przez upokorzenie na krzyżu. Św. Ambroży rozważając tę tajemnicę przechodzi niekiedy na ton modlitwy.

Unitarną wizję zbawienia - podkreśla dokument - św. Ambroży wyrażał w taki sposób, że na zasadzie typologii łączył Boży odpoczynek po dokonanym stworzeniu świata jako figurę z odpoczynkiem Chrystusa cierpiącego na krzyżu

\footnotetext{
${ }^{9}$ Por. Explanatio psalmi 1, 33, SAEMO 7, 80; Operosam diem 14, VoxP t. 30-31, s. 17.

10 Por. Operosam diem 17, VoxP t. 30-31, s. 20.

11 Por. tamże 18.

12 Tamże 18, VoxP t. 30-31, s. 20; Ambrosius De fide IV 8, 91; V 19, 228.
} 
w momencie dokonywania Zbawienia przez odkupieńczą śmierć ${ }^{13}$. Nawiązanie w dokumencie do myśli, że ,odpoczynek Boży [po stworzeniu] stanowił figurę odpoczynku Chrystusa na krzyżu" ${ }^{\text {14 }}$, zmierza w nauczaniu Biskupa do tego, by ukazać, że zbawczy zamiar Boga obejmuje w najpierwotniejszej perspektywie całość dziejów ludzkich, w których działa Zbawiciel, który „przyjął postać sługi, to jest pełnię ludzkiej doskonałości"15.

Wszystkie przytoczone w dokumencie stosowane przez św. Ambrożego określenia Chrystusa jako dawcy życia i zbawienia brzmią niezwykle entuzjastycznie. Ma to zresztą głębokie uzasadnienie dlatego, że określenia św. Ambrożego mówiące o bosko-ludzkiej naturze Chrystusa będą się przez następnych prawie dwieście lat pojawiać w chrystologicznych definicjach soborów i synodów - Soborów Efeskiego (431) i Chalcedońskiego (451) oraz synodu Lateraneńskiego (649), a niektóre jego traktaty, rzecz, jak wiadomo, rzadka, zostaną przełożone na język grecki ${ }^{16}$.

Następną ważną dziedziną w teologii św. Ambrożego, na którą zwraca uwagę dokument papieski, jest „nauka duchowa”, która w oparciu o alegoryczną egzegezę księgi Pieśni nad Pieśniami stwarza obraz bliskości wewnętrznej między Chrystusem i Kościołem przez analogię do oblubieńczej miłości tworzącej tło zjednoczenia duszy z Bogiem, które w połączeniu z „dyscypliną cnotliwego życia" prowadzi do mistycznego spotkania z Bogiem na drodze ascezy i oczyszczenia ${ }^{17}$. Całe życie człowieka winno prowadzić do spotkania z Chrystusem. „Przyjmij nas jako droga, umocnij jako prawda, ożyw jako życie" 18 - modlitewnie prosi.

W katechezach chrzcielnych mówi św. Ambroży z pewnym naciskiem o duchowym odrodzeniu przez chrzest i umocnieniu przez Eucharystię. List odczytuje to jako „dzieło aktualizacji sakramentów”, którego uświadomienie jest szczególnie ważne na początku jubileuszu rozpoczęcia trzeciego Millennium, ponieważ daje nadzieję na ożywienie życia sakramentalnego w zapowiadanej uroczyście przyszłości.

List przedstawia, że pod jeszcze jednym względem ważne jest nauczanie i działanie św. Ambrożego, ponieważ może ono przyczynić się do wzbogacenia współczesnej działalności ekumenicznej, o której nie zapominał też wielki Jubileusz 2000 Roku. Wynika to z faktu, że ten właśnie Biskup jest ,jednym z wybitnych Ojców jeszcze nie podzielonego Kościoła”, który do dziś otoczony jest szacunkiem i kultem zarówno na Wschodzie, jak i na Zachodzie ${ }^{19}$.

13 Por. Operosam diem 19; Hexameron VI 10, 76.

14 Operosam diem 19, VoxP t. 30-31, s. 21.

15 De fide V 8, 109; Operosam diem 20; VoxP t. 30-31, s. 21.

16 Por. m.in. De incarnationis Dominicae sacramento; zob. też Operosam diem 22.

17 Por. Operosam diem 24.

18 De bono mortis 12, 55, PSP 7, 167; Operosam diem 25.

19 Por. Operosam diem 27. 
Można u niego również znaleźć pewne akcenty gotowości do podejmowania dialogu z niechrześcijanami, skoro np. powiedział, że pozyskany poganin przestaje być zwolennikiem błędu, a staje się tym większym obrońcą wiary $^{20}$. Chociaż zmieniły się czasy, jego przykład - poucza przy tej okazji Ojciec Święty - może pociągać ludzi myślących z troską o przyszłych losach ludzkości ${ }^{21}$.

Chrystologiczne nastawienie Jubileuszu 2000 roku nie pozwoliło również zapomnieć o mariologicznym nauczaniu św. Ambrożego. Jest to ostatni punkt Listu Operosam diem, który przypomina, że u św. Ambrożego znajdujemy odgłosy gorącego nabożeństwa do Matki Chrystusa, obrazu Kościoła i wzorca życia chrześcijańskiego. Maryja - uczył - pozostawała pod krzyżem niewzruszona, tzn. że nie dotknęła Jej rozpacz na widok męki Syna, ale jeszcze nie jest określona jako współodkupicielka, bo przecież jedynym Odkupicielem był Jej Syn. List cytuje:

„Ona, która wiedziała, że śmierć Syna obróci się na dobro ogółu, oczekiwała, czy może także swoją śmiercią przyczyni się w jakiś sposób do ogólnego dobra. Ale męka Chrystusa nie potrzebowała wsparcia" ${ }^{22}$.

Na zakończenie Papież wyraża nadzieję, że ten rok kroczenia śladami świętego Biskupa zapewni wiernym wewnętrzny postęp i pomoże w pogłębieniu chrześcijańskiego świadectwa. Cytuje jego słowa:

„Niech będzie w was radość tego życia w czystym sumieniu, oczekiwanie śmierci z nadzieją na nieśmiertelność, pewność zmartwychwstania z łaską Chrystusa, prawda z prostotą, wiara z zaufaniem [...] kultura bez próżności”" ${ }^{\prime 2}$.

\section{JOHANNES PAUL II AM 1600. WIEDERKEHR DES TODESTAGES DES HL. AMBROSIUS \\ Apostolischer Brief Operosam Diem}

(Zusammenfassung)

In dieser kurzen Darstellung sind die wichtigsten Gedanken des Apostolischen Briefes Operosam diem vorgelegt, den der Papst Johannes Paul II zum 1600 Todestag des hl. Ambrosius publiziert hat. Man spricht hier von dem hl. Ambrosius als

\footnotetext{
${ }^{20}$ Por. Hexameron III 13, 55, PSP 4, 105; Operosam diem 30.

21 Por. Operosam diem 30.

22 De institutione virginis 7, 49; Operosam diem 32; VoxP t. 30-31, s. 31.

23 Epistola extra collectionem 14, 113; Operosam diem 33; VoxP t. 30-31, s. 32.
} 
Bischof, als Staatsmann, als Lehrer in der Theologie und als Verteidiger der Kirche und ihrer wahren Lehre. Besonders wichtig ist seine theologische Unterweisung, die einen großen Einfluss in der Geschichte ausgeübt hat. Von besonderer Bedeutung ist nämlich seine literarische Tätigkeit, die die schönen Gedanken in der Dogmatik und Exegese beinhaltet, sie übermittelt und entwickelt. 